\title{
Gastric strongyloidiasis and infection by the human T cell lymphotropic virus type 1 (HTLV-1)
}

\author{
Estrongiloidíase gástrica e infecção pelo vírus linfotrópico \\ humano do tipo 1 de células T (HTLV-1)

\section{José Roberto Lambertucci ${ }^{1}$, Flávia Costa Carvalho Leão ${ }^{1}$ and Alfredo José Afonso Barbosa²}

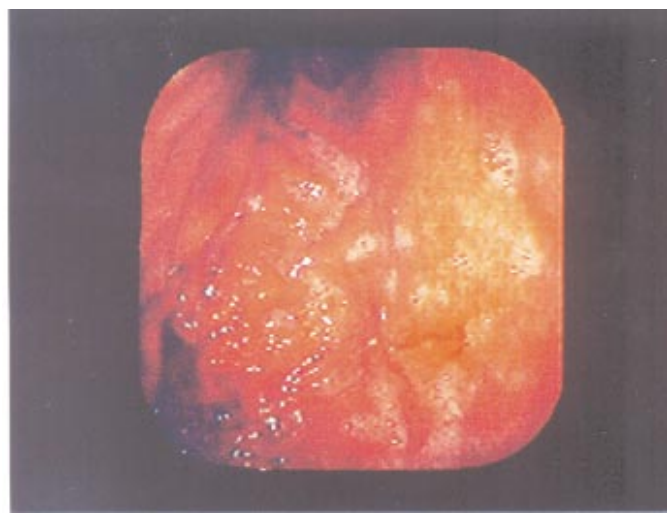

A
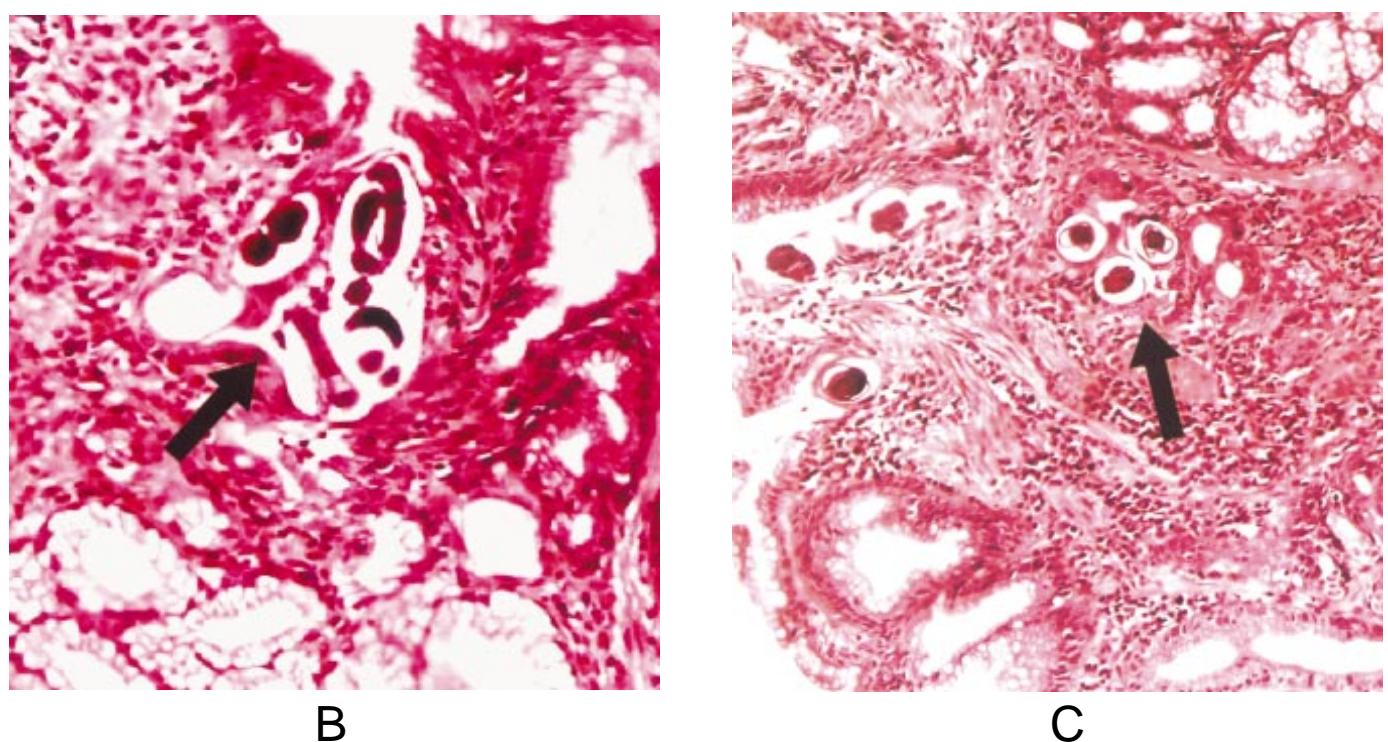

1. Serviço de Doenças Infecciosas e Parasitárias da Faculdade de Medicina da Universidade Federal de Minas Gerais, Belo Horizonte, MG, Brasil. 2. Departamento de Anatomia Patológica da Faculdade de Medicina da Universidade Federal de Minas Gerais, Belo Horizonte, MG.

Address to: Dr. José Roberto Lambertucci. Deptº de Clínica Médica/FM/UFMG. Av. Alfredo Balena 190, 30130-100 Belo Horizonte, MG, Brasil. e-mail: lamber@net.em.com.br

Recebido para publicação em 12/6/2003

Aceito em 16/6/2003 
A 53-year-old man presented with a two-year history of abdominal pain, bloating and malaise. For the last 6 months the pain was more intense in the epigastrium and he also presented nausea and vomiting at least three times in the course of one week. There was a weight loss of $18 \mathrm{~kg}$ in the same period. He was a heavy drinker and his symptoms, initially, were attributed to alcohol abuse. An upper endoscopy was performed and with a diagnosis of gastritis he was treated with $\mathrm{H} 2$ receptor antagonists. He was admitted to hospital emaciated and with generalized edema. His hemoglobin was $7.3 \mathrm{~g} / \mathrm{dl}$ and the white blood cell count was $7,800 / \mathrm{mm}^{3}$ with no eosinophils. Serum albumin was $1 \mathrm{~g} / \mathrm{dl}$. Another upper endoscopy confirmed the diagnosis of gastritis with enanthema in the body and antrum (Figure A). Gastric biopsy revealed a moderate inflammatory infiltrate in gastric mucosa and distortion of the crypts due to numerous filariform larvae consistent with Strongyloides stercoralis (Figures B and C - black arrows). Examination of a stool sample showed rhabditiform larvae. The patient was treated with a single dose of ivermectin $(12 \mathrm{mg})$, followed by thiabendazole $(1,500 \mathrm{mg} / \mathrm{day})$ for 30 days. He also received parenteral nutrition. While in hospital, he developed bilateral pneumonia, sepsis and respiratory failure. After admission in the intensive care unit he was treated with antibiotics and kept in mechanical ventilation for 20 days, when he finally recovered and was returned to the infirmary. He was discharged from the hospital 10 days later in good clinical condition. A series of laboratory tests was performed in an attempt to disclose an underlying disease - such as, gastrointestinal cancer, lymphoma, or acquired immunodeficiency syndrome without success. An ELISA for HTLV $1 / 2$ resulted positive and infection by HTLV-1 was confirmed by western blot. The association of strongyloidiasis with infection by HTLV-1 has been described but this is the first case of severe gastric strongyloidiasis reported in association with HTLV-1 infection.
O paciente, de 53 anos de idade, relatava a presença de dor abdominal, sensação de empachamento e mal estar nos últimos dois anos. Nos últimos seis meses, houve intensificação da dor abdominal, em especial no epigástrio, além de náuseas e vômitos que o incomodavam cerca de três vezes por semana. Anotou a perda de peso corporal de 18kg. Relatou que ingeria bebidas alcoólicas em grande quantidade e os sintomas apresentados foram atribuídos ao alcoolismo. A endoscopia digestiva alta revelou a presença de gastrite e, por isso, foi tratado com antagonistas de receptores H2. À internação, encontrava-se emagrecido e com edema generalizado. A hemoglobina era de $7,3 \mathrm{~g} / \mathrm{dl}$ e os leucócitos totais de $7.800 / \mathrm{mm}^{3}$, sem eosinófilos. A albumina sérica era de $1 \mathrm{~g} / \mathrm{dl}$. Outra endoscopia digestiva alta em nosso hospital confirmou a presença de gastrite enantematosa no corpo e antro (Figura A). A biópsia gástrica revelou infiltrado inflamatório moderado da mucosa gástrica e distorção das criptas devido à presença de larvas filariformes reconhecidas como larvas de Strongyloides stercoralis (Figuras $\mathrm{B}$ e $\mathrm{C}$ - setas pretas). $\mathrm{O}$ exame das fezes mostrou a presença de larvas rabditóides. O paciente foi tratado com dose única de ivermectina $(12 \mathrm{mg})$, seguida de tiabendazol (1.500mg/dia) por 30 dias. Recebeu também alimentação parenteral. Durante a internação, evoluiu com pneumonia, sepse e insuficiência respiratória. No centro de terapia intensiva recebeu antibióticos e foi mantido em respiração mecânica por 20 dias e, após melhora clínica, retornou à enfermaria. Dez dias mais tarde recebeu alta hospitalar em bom estado geral. Ele submeteu-se a uma série de exames de laboratório em busca de doença subjacente que explicasse o quadro clínico - como, câncer gastrointestinal, linfoma, síndrome da imunodeficiência adquirida -, sem sucesso. O teste de ELISA para o HTLV 1/2 revelou-se positivo e a infecção pelo HTLV-1 foi confirmada pelo western blot. A associação da infecção pelo HTLV-1 e estrongiloidíase, já descrita, apresenta características fisiopatológicas peculiares. Relatamos aqui o primeiro caso de associação entre a infecção pelo HTLV-1 e estrongiloidíase gástrica grave.

\section{REFERENCES}

1. Porto MAF, Muniz A, Oliveira Júnior J, Carvalho EM. Implicações clínicas e imunológicas da associação entre o HTLV-1 e a estrongiloidíase. Revista da Sociedade Brasileira de Medicina Tropical 35: 641-649, 2002.

2. Shekhar KC, Krishnan R, Pathmanathan R, Fook CS. Gastric strongyloidiasis in a Malaysian patient. Southeast Asian
Journal of Tropical Medicine and Public Health 28: 158-160, 1997.

3. Wurtz R, Mirot M, Fronda G, Peters C, Kocka F. Gastric infection by Strongyloides stercoralis. The American Journal of Tropical Medicine and Hygiene 51: 339-340, 1994. 